\title{
RFC4 Gene
}

National Cancer Institute

\section{Source}

National Cancer Institute. RFC4 Gene. NCI Thesaurus. Code C158525.

This gene is involved in DNA elong ation during replication. 